\title{
THIN FILM POLYCRYSTALLINE SILICON SOLAR CELLS
}

Quarterly Technical Progress Report No. 3 for Period April 1-June 30, 1980

By

K. R. Sarma

M. J. Rice

R. Legge

R. J. Ellis

June 1980

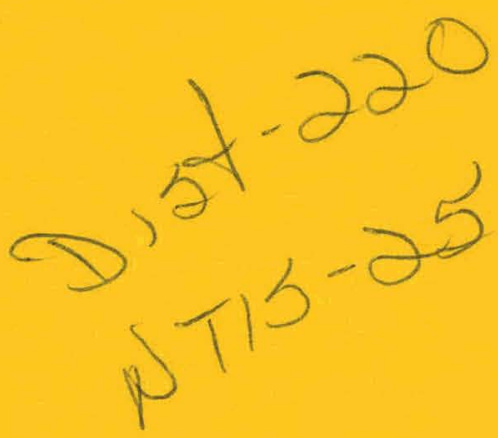

Work Performed Under Contract No. AC02-77CH00178

Motorola, Inc.

Phoenix, Arizona

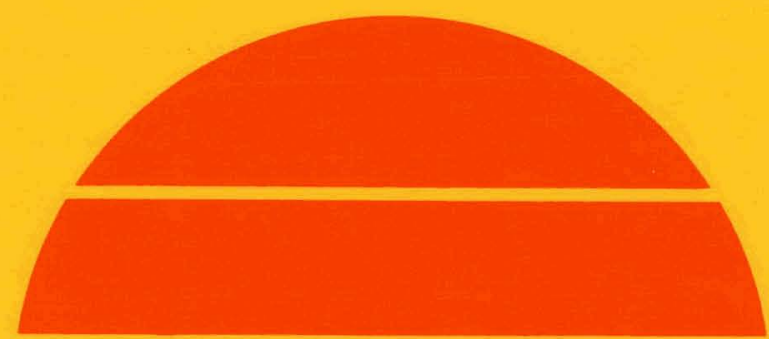

\section{U.S. Department of Energy}




\section{DISCLAIMER}

This report was prepared as an account of work sponsored by an agency of the United States Government. Neither the United States Government nor any agency Thereof, nor any of their employees, makes any warranty, express or implied, or assumes any legal liability or responsibility for the accuracy, completeness, or usefulness of any information, apparatus, product, or process disclosed, or represents that its use would not infringe privately owned rights. Reference herein to any specific commercial product, process, or service by trade name, trademark, manufacturer, or otherwise does not necessarily constitute or imply its endorsement, recommendation, or favoring by the United States Government or any agency thereof. The views and opinions of authors expressed herein do not necessarily state or reflect those of the United States Government or any agency thereof. 


\section{DISCLAIMER}

Portions of this document may be illegible in electronic image products. Images are produced from the best available original document. 


\section{DISCLAIMER}

"This book was prepared as an account of work sponsored by an agency of the United States Government. Neither the United Statcs Liovernment nor any agenty lliereof, nor any of their employees, makes any warranty, express or implied, or assumes any legal liability or responsibility for the accuracy, cumpleteness, or uscfulness of any information, apparntus, product, or process disclosed, or represents that its use would not infringe privately owned rights. Reference herein to any specific commercial product, process, or service by trade name, trademark, manufacturer, or otherwise, does not necessarily constitute or imply its endorsement, recommendation, or favoring by the United States Government or any agency thereof. The views and opinions of authors expressed herein do not necessarily state or reflect those of the United States Government or any agency thereof."

This report has been reproduced directly from the best available copy.

Available from the National Technical Information Service, U. S. Department of Commerce, Springfield, Virginia 22161.

Price: Printed Copy A03

Microfiche $\mathrm{A} 01$ 
THIN FILM POLYCRYSTALLINE SILICON SOLAR CELLS

\author{
QUARTERLY TECHNICAL PROGRESS REPORT NO, 3 \\ FOR PERIOD \\ 1 APRIL $1980=30$ JUNE 1980
}

$K \cdot R$. SARMA, M.J. RICE, R. LEGGE, R.J. ELLIS

\begin{abstract}
JUNE 1980
UNITED STATES

DEPARTMENT OF ENERGY

DIVISION OF SOLAR TECHNOLOGY

AND

SOLAR ENERGY RESEARCH INSTITUTE

UMNDER DOE SUBCONTRACT NO XS-9-8277-1
\end{abstract}

MOTOROLA PROJECT NO. 2377 


\section{PREFACE}

This Quarterly Report No. 3, covering the period Aprll 1, 1980 to June 30, 1980, was prepared by the Solar Energy R\&D Department, I. A. Lesk, Manager, Motorola.Inc., Phoenix, Arizona 85008. This report describes the work performed under SERI Contract No. XS-9-8277-1. K. R. Sarma is the prinicpal investigator. Others who participated in this program are R. W. Gurtler, M. J. Rice, R. N. Legge, R. J. Ellils and W. Sallina. 


\section{ABSTRACT}

During this third quarter of the program, the high pressure plasma (hpp) deposition process has been thoroughly evaluated using $\mathrm{SiHCl}_{3}$ and $\mathrm{SiCl}_{4}$ silicon source gases, by the gas chromatographic analysis of the effluent gases from the reactor. Both the deposition efficiency and reactor throughput rate were found to be consistently higher for hpp mode of operation compared to conventional CVD mode. The figure of merit for various chlorosilanes as a silicon source gas for hpp deposition is discussed. A new continuous silicon film deposition scheme is developed, and system design is initiated. This new system employs gas interlocks and eliminates the need for gas curtains which have been found to be problematic. Solar cells $(2 \mathrm{~cm} \times 2 \mathrm{~cm}$ area) with AM1 efficioncies of up to $12 \%$ were fabricated on RTR grain enhanced hpp deposited films. The parameters of a $12 \%$ cell under simulated AM1 IIlumination were: $v_{O C}=0.582$ volts, $J_{S C}=28.3 \mathrm{~mA} / \mathrm{cm}^{2}$ and F.F. $=73.0 \%$. 
TABLE OF CONTENTS

SECTION NUMBER

TITLE

PAGE

1.0

Introduction

2.0

Characterization of Plasma Deposition Process

2.1

Experimental Results

DIscussion

silicon Deposition Mechanisms

Kinetic Effects

Tronsport Effects

Cholce of Sillicon Source Gas

5.1

Solar Cells on RTR Silicon Grown from Float

Zone SIlicon Feedstock

5.2

Solar Colle on RTR Silicon Grown from CVD

Feedstock.

Filmis

6.0

Plans for Next Quarter 

Rate $=30$ LPM: Substrate Temperature $=1100^{\circ} \mathrm{C}$ ). Bearing Gas (Total Reactant Flow Rate $=30$ LPM, Substrate Temperature $=1100^{\circ} \mathrm{C}$.

Deposition Efficiency vs. Substrate Temperature Using $\mathrm{SiHCl}_{3}$ as Sillicon Source Gas. (Total Reactant Flow Rate $=30$ (PM).

Reactor Throughput as a Function of Concentration

Equilibrium Deposition Efficiency as a Function of Concentration with Different Chlorosilane Sources for $\mathrm{T}=1100^{\circ} \mathrm{C}$ and $\mathrm{P}=1 \mathrm{~atm}$. in References $(4-8)$. Mechanism in a Conventional Cold Wall CVD Reactor.

Schematic II.lustration of the HPP Deposition Model. Soret Diffusion is Expected to be Important only in the Initial Region of the Deposition Reactor.

Relative Concentrations of Various Species Containing $\mathrm{Si}, \mathrm{H}, \mathrm{Cl}$ as a Function of Temperature for $\mathrm{P}=1 \mathrm{~atm}$. and $\mathrm{Cl} / \mathrm{H}=0.1$ (Reference 12). Microcrystaliline Silicon Deposition System Employing Gas Interlocks. Revealed by 6 Minutes Wright Etching.

Dislocation Density of the Bulk of the Cell Shown in Figure 11, as Revealed by Wright Etching the Cross Sectional Samples. 


\section{LIST OF TABLES}

TABLE NUMBER

TITLE

PAGE

1

Summary of Results Obtalned Using $\mathrm{SiHCl}_{3}$ as

4 Silicon Source. Gas.

2 Summary of Results Obtained Using $\mathrm{SiCl}_{4}$ as

8 Sillicon Source Gas.

Comparisons Between Varlous Chlorosilanes.

Summary of Results Obtained Using Float Zone Sllicon. Feedstock.

RTR Solar Cell Performance trom CVŨ Feedstock.

34

Summary of Typlcal Solar Cells from Grain Enhanced HPP Deposited Films. 
The objectives of this research program are: a) investigation of a semicontinuous plasma deposition system as a means for efficient, high rate deposition of polycrystalline silicon films, b) development of low-cost reuseable substrates for deposition and shear separation of the silicon flims, c) optimization and subsequent grain enhancement of the films through laser RTR recrystallization, and d) demonstration of at least $12 \%$ efficient, large area (greater than $10 \mathrm{~cm}^{2}$ ) solar cells fabricated on grain-enhanced silicon films.

Durlng this quarter, we have characterized the plasma depositon process using $\mathrm{SiHCl}_{3}$ and $\mathrm{SiCl}_{4}$ as the silicon source gases gy gas chromatographic analysis of the reactor effluent gases. Deposition efficlencles were determined as a function of chlorosilane concentration and substrate temperature. Comparisons were made in the deposition reactor performance between the CVD and plasma deposition modes under otherwise identical conditions. Under practical silicon film deposition conditions, deposition efficlencies and sllicon flim throughput rates were found to be consistently higher with the plasma deposition mode of operation compared to the CVD mode. The observed results are discussed and explained qualitatively from thermodynamlc, kinetic and mass transport considerations.

A new continuous silicon film deposition scheme has been developed. This new scheme employs gas interlocks and eliminates the requirement for gas seals used in the present semicontinuous system and which are found to be problematic. A series of experiments has been performed in the grain enhancement and solar cell fabrication areas aimed at determining the factors limiting the performance of solar cells fabricated on RTR grain enhanced plasma deposited silicon films. The results of these experiments suggest that the detrimental chemical impurities in these films are at an inconsequential level, and it is the 
presence of defects (primarily dislocations) which are currently limiting the performance of the solar cells. However, in the latest batch of solar cells fabricated on RTR grain enhanced plasma deposited films, we have observed AM1 conversion efficiencies of up to $12 \%$ on $4 \mathrm{~cm}^{2}$ area cells. 
We have continued characterization of the high pressure plasma (hpp) deposition process with various experimental parameters including the type of silicon bearing gas used, reactant concentration, total reactant flow rate, and substrate temperature during deposition. Experiments aimed at comparing the silicon deposition process under HPP and conventional CVD modes were also performed. Gas chromatography has been used to evauate each silicon deposition process; detalls of the gas chromatographic procedures were described earlier $(1,2$,$) . The sllicon deposition process is characterized by determining$ the efficiency of silicon deposition; the error in deposition efficiency determined by gas chromatographic analysis is estimated to be within $\pm 0.5 \%$.

In the following we present the experimental results and explain them on a qualitative basis using thermodynamic, kinetic and mass transport considerations. We also discuss the suitability of various chlorosilanes as silicon source gases in the hpp deposition process.

\section{$2.1 \quad$ EXPERIMENTAL RESULTS}

Table 1 summarizes the results, obtained using $\mathrm{SiHCl}_{3}$ as the silicon source gass. Figure 1 shows the effect of chlorosilane concentration on deposition efficiency when the substrate temperature and total reactant flow rate are kept constant at $1100^{\circ} \mathrm{C}$ and $30 \mathrm{LHM}$ respectively. From the reactor dimensions $(5 \mathrm{~cm} \times 5 \mathrm{~cm} \times 60 \mathrm{~cm}$ ), the flow velocity and residence time can be calculated to be $20 \mathrm{~cm} / \mathrm{sec}$. and $3 \mathrm{sec}$. respectively. Renolds number calculations for all the reactant flows employed indicated that the flow will be in the turbulent regime. Also diffusion length calculations for the heaviest molecule $\left(\mathrm{SiCl}_{4}\right)$ in the reactor system using the diffusion coefficient $\left(6.3 \mathrm{~cm}^{2} / \mathrm{sec}\right)$ (3) and residence 
TABLE 1

SUMMARY OF RESULTS OBTAINED USING

$\mathrm{SiHCl}_{3}$ AS SILICON SOURCE GAS.

\begin{tabular}{|c|c|c|c|c|c|}
\hline \multirow[b]{2}{*}{$T\left({ }^{\circ} \mathrm{C}\right)$} & \multirow[b]{2}{*}{ MODE } & \multirow[b]{2}{*}{ FLOW (LPM) } & \multicolumn{3}{|c|}{ DEPOSITION EFFICIENCY } \\
\hline & & & $\mathrm{Cl} / \mathrm{H}=.04$ & $\mathrm{Cl} / \mathrm{H}=0.08$ & $\mathrm{Cl} / \mathrm{H}=0.1$ \\
\hline \multirow[t]{2}{*}{1050} & $\begin{array}{l}\text { CVD } \\
\text { HPP }\end{array}$ & $\begin{array}{l}15 \\
15\end{array}$ & $\begin{array}{l}40.5 \\
49.3\end{array}$ & $\begin{array}{l}30.9 \\
35.6\end{array}$ & $\begin{array}{l}26.5 \\
29.8\end{array}$ \\
\hline & $\begin{array}{l}\text { CVD } \\
\text { HPP }\end{array}$ & $\begin{array}{l}30 \\
30\end{array}$ & $\begin{array}{l}39.0 \\
53.5\end{array}$ & $\begin{array}{l}25.0 \\
35.1\end{array}$ & $\begin{array}{l}21.7 \\
32.7\end{array}$ \\
\hline \multirow[t]{2}{*}{1100} & $\begin{array}{l}\text { CVD } \\
\text { HPP }\end{array}$ & $\begin{array}{l}15 \\
15\end{array}$ & $\begin{array}{l}47.3 \\
54.3\end{array}$ & $\begin{array}{l}35.7 \\
38.5\end{array}$ & $\begin{array}{l}32.3 \\
33.5\end{array}$ \\
\hline & $\begin{array}{l}\text { CVD } \\
\text { HPP }\end{array}$ & $\begin{array}{l}30 \\
30\end{array}$ & $\begin{array}{l}52.2 \\
55.1\end{array}$ & $\begin{array}{l}36.1 \\
37.9\end{array}$ & $\begin{array}{l}\overline{3} 1.5 \\
34.0\end{array}$ \\
\hline \multirow[t]{2}{*}{1150} & $\begin{array}{l}\text { CVD } \\
\text { HPP }\end{array}$ & $\begin{array}{l}15 \\
15\end{array}$ & $\begin{array}{l}51.9 \\
49.3\end{array}$ & $\begin{array}{l}34.2 \\
35.6\end{array}$ & $\begin{array}{l}30.7 \\
32.3\end{array}$ \\
\hline & $\begin{array}{l}\text { CVD } \\
\text { HPP }\end{array}$ & $\begin{array}{l}30 \\
30\end{array}$ & $\begin{array}{l}53.9 \\
55.7\end{array}$ & $\begin{array}{l}31.7 \\
35.8\end{array}$ & $\begin{array}{l}27.8 \\
31.7\end{array}$ \\
\hline \multirow[t]{2}{*}{1200} & $\begin{array}{l}\text { CVD } \\
\text { HPP }\end{array}$ & $\begin{array}{l}15 \\
15\end{array}$ & $\begin{array}{l}48.0 \\
49 . \dot{8}\end{array}$ & $\begin{array}{l}34.9 \\
37.3\end{array}$ & $\begin{array}{l}30.5 \\
33.2\end{array}$ \\
\hline & $\begin{array}{l}\text { CVD } \\
\text { HPP }\end{array}$ & $\begin{array}{l}30 \\
30\end{array}$ & $\begin{array}{l}51.6 \\
68.1\end{array}$ & $\begin{array}{l}31.4 \\
39.0\end{array}$ & 29.0 \\
\hline
\end{tabular}




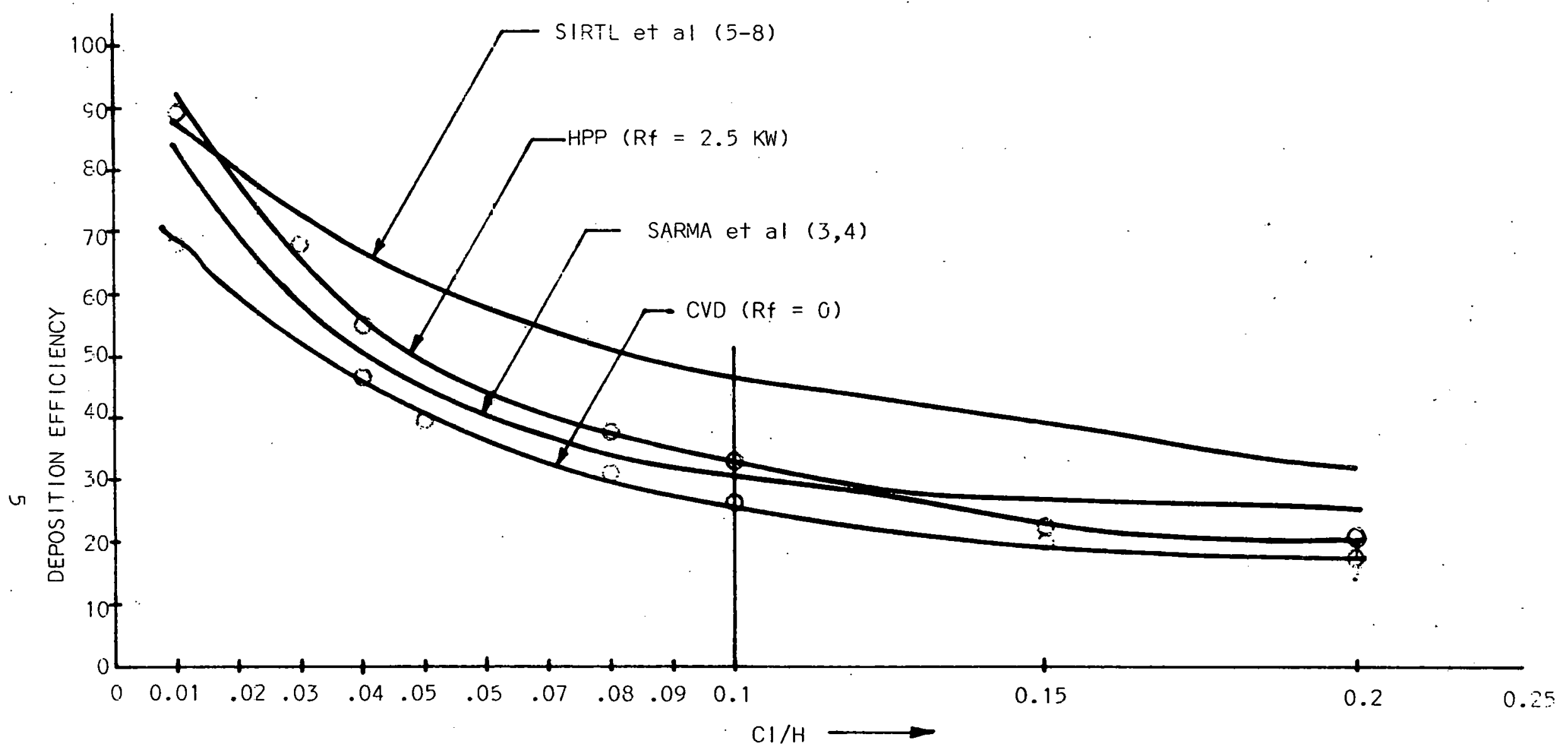

FIGURE 1: DEPOSITION EFFICIENCY USING SIHCI 3 AS THE SILICON-BEARING GAS (TOTAL REACTANT GAS FLOW RATE $=30^{\circ}$ LPM: SUBSTRATE TEMPERTLIRE $=1100^{\circ} \mathrm{C}$ ). 
time ( 3 sec.) indicated that it is approximately the same as the

reactor cross sectional size. From these considerations, good gas mixing can be expected in the reactor system. Along with the experimental data under CVD and HPP conditions, data from theoretical calculations by SirtI and Sarma are also shown in Figure 1. (The two theoretical curves presented in Figure 1 will be discussed later in this section).

As can be seen in Figure 1, observed deposition efficiency is higher for the HPP mode fhan for the corresponding CVD mode. Also, in the HPP mode, observed efficiency is higher than predicted by thermodynamic equilibrium calculations (4.5) (Sarma) for $\mathrm{Cl} / \mathrm{H}<0.1$. For $\mathrm{Cl} / \mathrm{H}>0.1$ the HPP effieiencies are lower than calculated equilibrium values. Observed CVD efficiencies are consistently lower than calculated equilibrium values. In some experiments performed with exceedingly small reactant flow rates (high residence times) to assure equilibrium, the CVD efficiencies approached the equilibrium efficiencies more closely, but were never found to exceed the equilibrium values predicted from our calculations.

of the two theoretical curves presented in Figure 1, one is obtained from our work $(4, b)$ and one. from sirtl et al. publications $(6-8)$. As can be seen in Figuré I, while the two theoretical curves are in qualitative agreement regarding the variation of deposition efficiency with concentration, they differ quantitatively. Sirtl's calculations predict much higher deposition efficiencies than ours. Sirtl's calculations (6-8) were available when we started work on this contract. Hence, our calculations were aimed at extending Sirtl's calculations to the conditions pertaining the HPP deposition (plasma temperatures up to 5000K). Thus, we employed the same calculation technique as Sirtl et al. (free energy minimization technique) for calculating the chemical thermodynamic equilibrium. We have not yet clearly identified the reasons for disagreement between the two calculation results. However, it should be 
pointed out that Sirtl et al. used the thermodynamic data available in the year 1972, and we have used data from JANAF tables (9) in the year: 1978. JANAF tables are regularly updated with more acceptable thermodynamic data. Hence, it is possible that the difference between the two may be associated with the thermodynamic data used and the species considered. We plan to investigate this further. It is worth pointing out that we were not able to locate any experimental work in the literature in which the silicon deposition efficiency (using $\mathrm{SiHCl}_{3}$ as the silicon source gas) appraoched the equilibrium value predicted by sirtl et al. calculations.

Table 2 summarizes the results obtained using $\mathrm{SiCl}_{4}$ as a source gas. Figure 2 shows the effect of chlorosilane concentration on the deposition efficiency. $\mathrm{SiCl}_{4}$ source gas deposition differs from $\mathrm{SiHCl}_{3}$; in particular, etching reactions become important with $\mathrm{SiCl}_{4}$ at fairly low reactant concentrations. As can be seen in Figure 2, HPP efficiencies are higher than CVD efficiencies over most of the concentration range. For $\mathrm{Cl} / \mathrm{H}>0.15$, CVD efficiency appears to be slightly higher than the HPP value. While the difference between the two ( 1.0\% for $\mathrm{Cl} / \mathrm{H}=0.2)$ appears to be comparable to the accuracy of the measurement, it is found to be real as inferred from the result of a number of repetitions of this experiment. Further it can be seen from Figure 2 that the experimental efficiencies are higher than our predicted equilibrium values and lower than those of Sirtl et al. Also our calculations predict etching for $\mathrm{Cl} / \mathrm{H} \simeq 0.125$ and sirtl et. al. predict etching for $\mathrm{Cl} / \mathrm{H} \simeq 0.3$; experimentally, etching has not been observed for $\mathrm{Cl} / \mathrm{H}$ ratios of up to 0.3 .

Figure 3 shows the effect of substrate temperature during deposition on the efficiency. This figure shows data for two different concentrations, $\mathrm{Cl} / \mathrm{H}=0.08$ and 0.1 , when using $\mathrm{SiHCl}_{3}$ as the sllicon source gas. The maximum in deposition 
TABLE ?

SUMMARY OF RESULTS OBTAINED USING

$\mathrm{SICl}_{4}$. AS SILICON SOURCE GAS

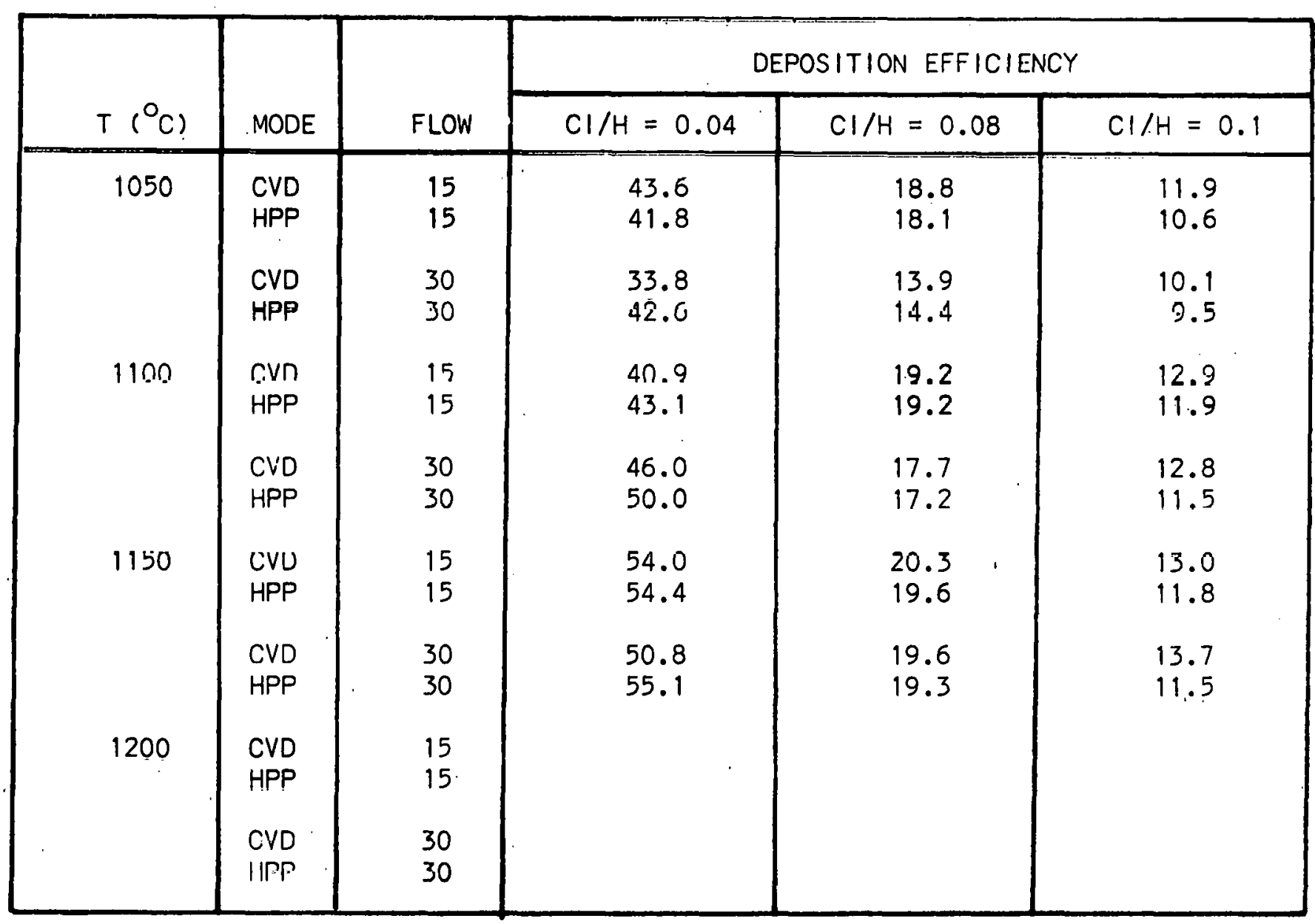




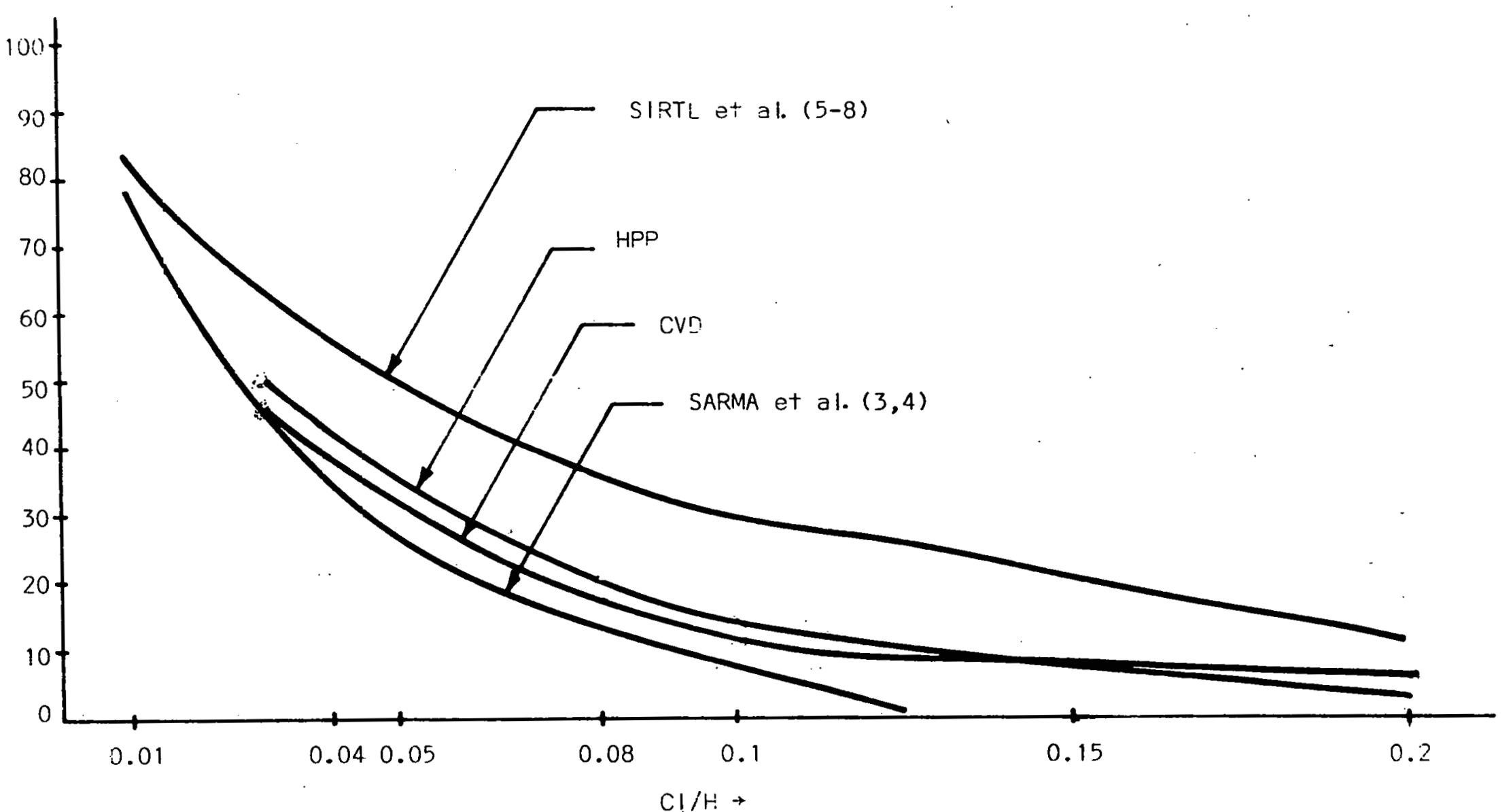

FIGURE 2: DEPOSITION EFFICINECY USING SICI AS THE SILICON BEARING GAS (TOTAL: REACTANT FLOIV RATE $=30 \mathrm{LPM}$, SUBSTRATE TEMPERATURE $=1100^{\circ} \mathrm{C}$ ) 


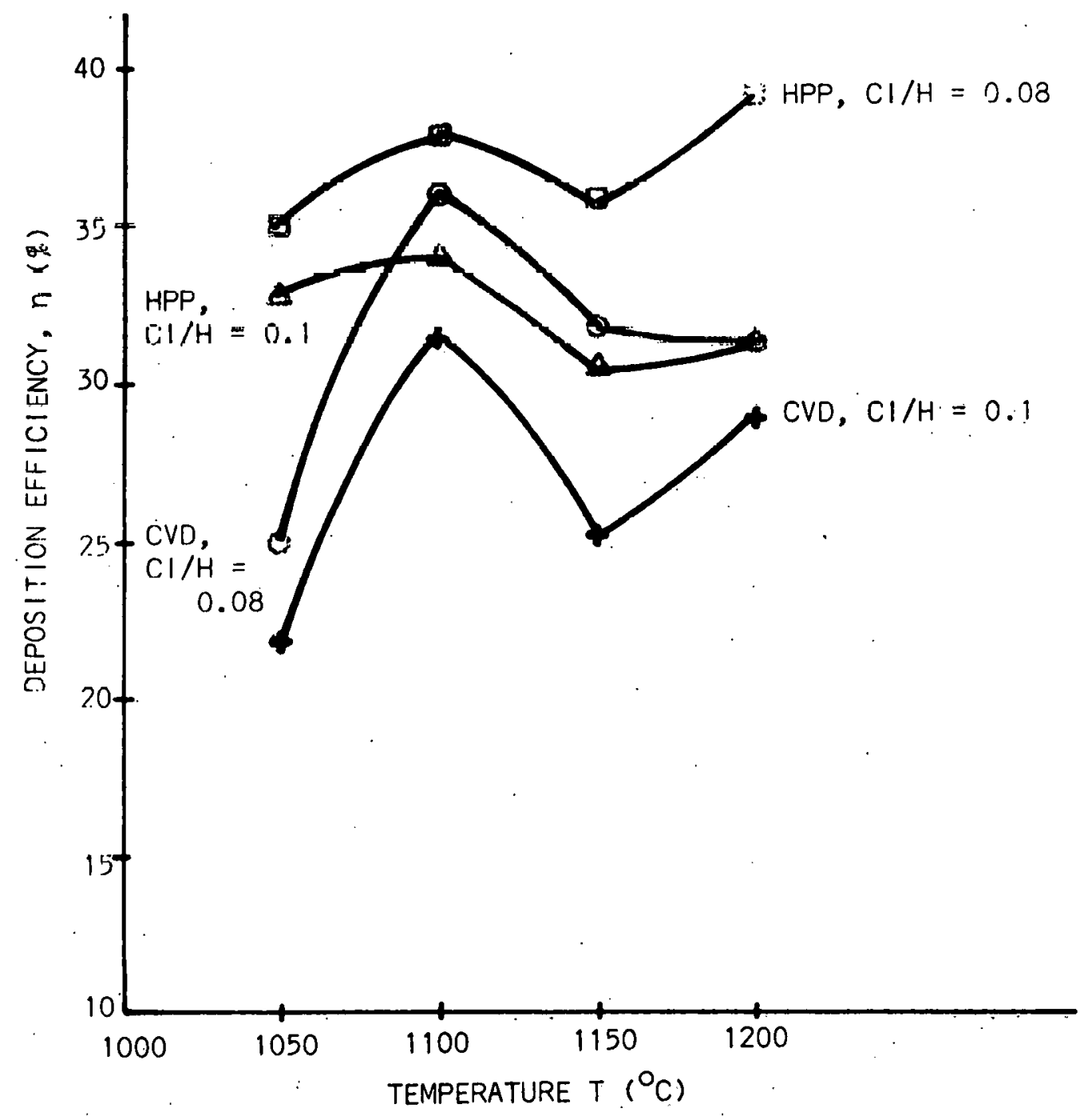

FIGURE 3: DEFOSITIONN FFFICIENCY VS. SUBSTRATE TEMPERATIIRF. USING SIHCI AS SILICON SOURCE GAS. (TOTAL REACTANT FLOW RATE $=30$ (PM). 
efficiency at around $1100^{\circ} \mathrm{C}$ is in qualitative agreement with Sirtl et al. equlibrium calculations. (Our calculations do not include low temperatures and hence comparisons could not be made.) Figure 3 indicates that the HPP efficiencies are consistantly higher than CVD efficiencies.

Figure 4 shows reactor throughput (given in terms of a constant times the grams of silicon deposited per minute) calculated from data in Figures 1 and 2 . Reactor throughput is an important parameter since it determines the number of reactors (capital) required for a given capacity which in turn determines production floor space requirements. As seen in Figure 4 , when using $\mathrm{SiCl}_{4}$ as the silicon source gas, a maximum in throughput occurs at a concentration, $\mathrm{Cl} / \mathrm{H}$, of about 0.05 . Using $\mathrm{SiHCl}_{3}$ as the silicon source gas, throughput increases continuously with concentration. However, for higher concentrations, silicon powder formation due to excessive gas phase nucleation becomes a severe problem. Thus the onset of powder formation sets an upper limit to the concentration $(\mathrm{Cl} / \mathrm{H}$ ratio) that can be employed and the reactor throughput achieved. This concentration limit is found to be around a $\mathrm{Cl} / \mathrm{H}$ ratio of 0.1 . This concentration limit is found to be somewhat higher for CVD compared to HPP deposition. Thus from figure 4 it can be seen that, comparing $\mathrm{SiCl}_{4}$ and $\mathrm{SiHCl}_{3}$ as a silicon source gas, reactor throughput is higher in the HP.P mode than in the CVD mode under practical silicon deposition conditions. Also, the practical reactor throughput is about a factor of two higher for $\mathrm{SiHCl}_{3}$ compared to a $\mathrm{SiCl}_{4}$ source.

\section{$2.2 \quad$ DISCUSSION}

\subsubsection{THERMODYNAMIC FACTORS}

While, in general, practical silicon deposition reactors do not operate under 


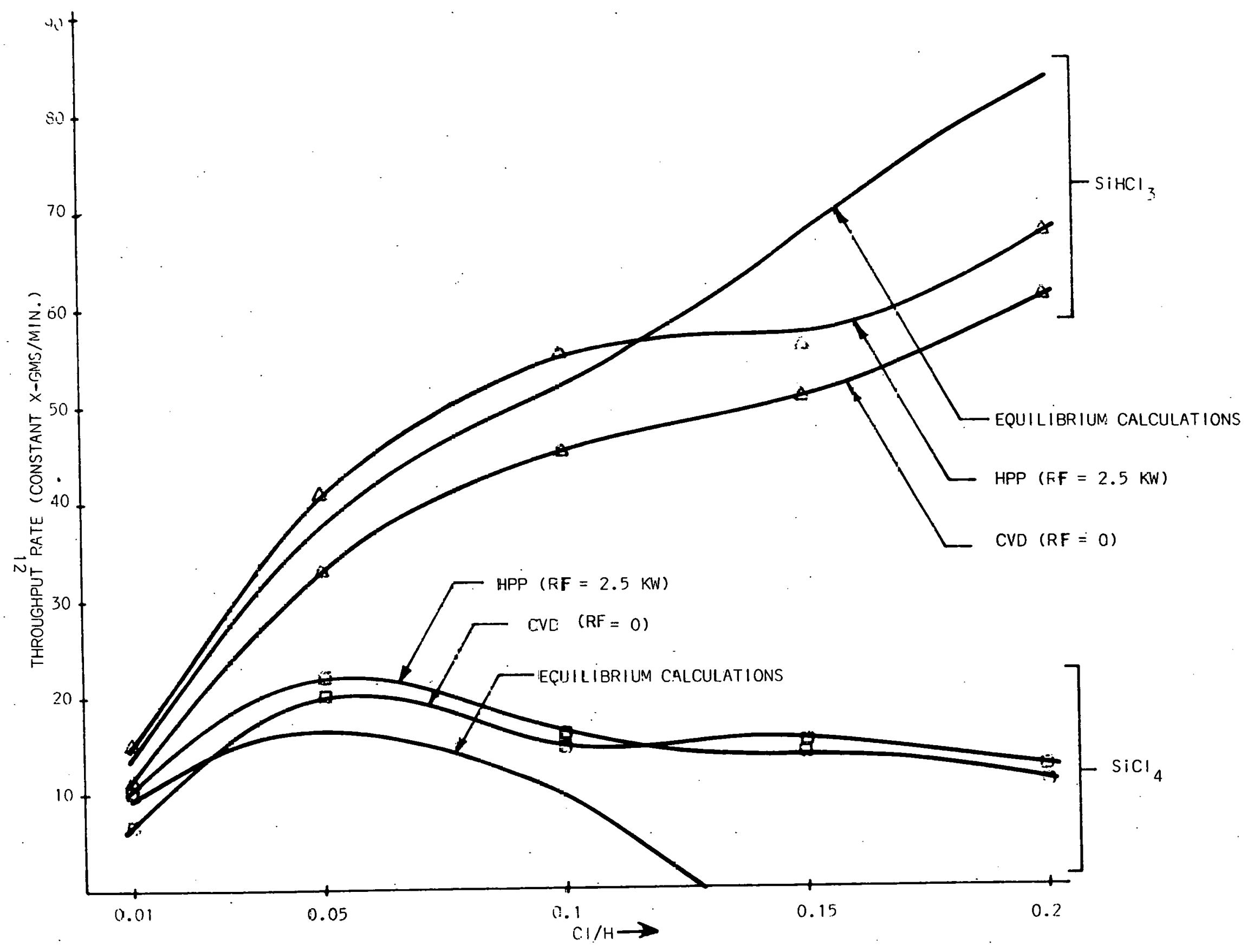

: MGIRE 4: REACTOR THROUGHPUT AS A FINCTION OF CONEENTFATION. 
equilibrium conditions, consideration of thermodynamic equilibrium helps one to predict the range of performance that can be expected. For example, by examining the results of equilibrium calculations $(4,5)$ such as those in Figure 5 , one can easily predict the relative performance of various chlorosilanes in a deposition reactor. Figure 5 shows the equllibrium deposition efficlencies for $\mathrm{SiH}_{2} \mathrm{Cl}_{2}, \mathrm{SiHCl}_{3}$ and $\mathrm{SiCl}_{4}$ sources as a function of concentration for a substrate temperature of $1100^{\circ} \mathrm{C}$ and reactor pressure of $1 \mathrm{~atm}$. Experimental deposition efficiencles are in qualltative agreement with the results of equilibrium calculation: i.e., deposition efficlencles are the highest for $\mathrm{SiH}_{2} \mathrm{Cl}_{2}$ and lowest for $\mathrm{SiCl}_{4}$, and deposition efficlency decreases for all these chlorosilanes with increasing concentration.

Similarly effect of substrate temperature can be examined from the equilibrium digaram shown in Figure 6. In this figure, $\frac{\mathrm{si}}{\mathrm{Cl}}$ ratlo in the gas phase in equilibrium is plotted as a function of concentration ( $\mathrm{Cl} / \mathrm{H}$ ratlo) of the reactor input gas stream for varlous temperatures. Using Figure 6, the deposition efficiency, $n$, can be calculated using the equation

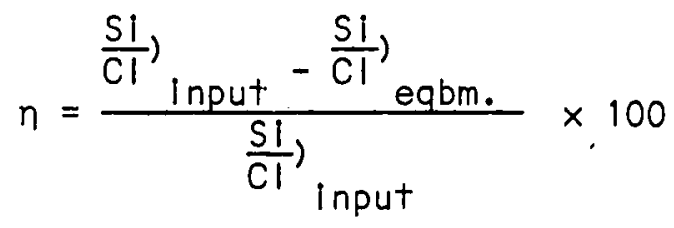

where $\mathrm{Si} / \mathrm{Cl})_{\text {input }}$ is determined by the chlorosilane source used. For example for $\left.\mathrm{SiH}_{2} \mathrm{Cl}_{2}, \mathrm{Si} / \mathrm{Cl}\right)_{\text {input }}=0.5$ and for $\left.\mathrm{SiCl}_{4}, \mathrm{Si}^{\prime} \mathrm{Cl}\right)_{\text {input }}=0.25$.

Thus from the above expression we can see that for a given source, efficiency wlll be higher when Si/Cl) eqbm. is lower. In Figure 6 we have used Sirtl et al. data (6-8) for low temperatures $(T \leq 1700 \mathrm{~K})$ and our calculated data $(4,5)$ for high temperatures (T>1700K). Since we use this figure only to explain trends in silicon deposition, quantitative disagreement between the two sets of data is not of concern. From Figure 6, it can be seen that $\mathrm{Si} / \mathrm{Cl}$ ) eqbm. increases with 


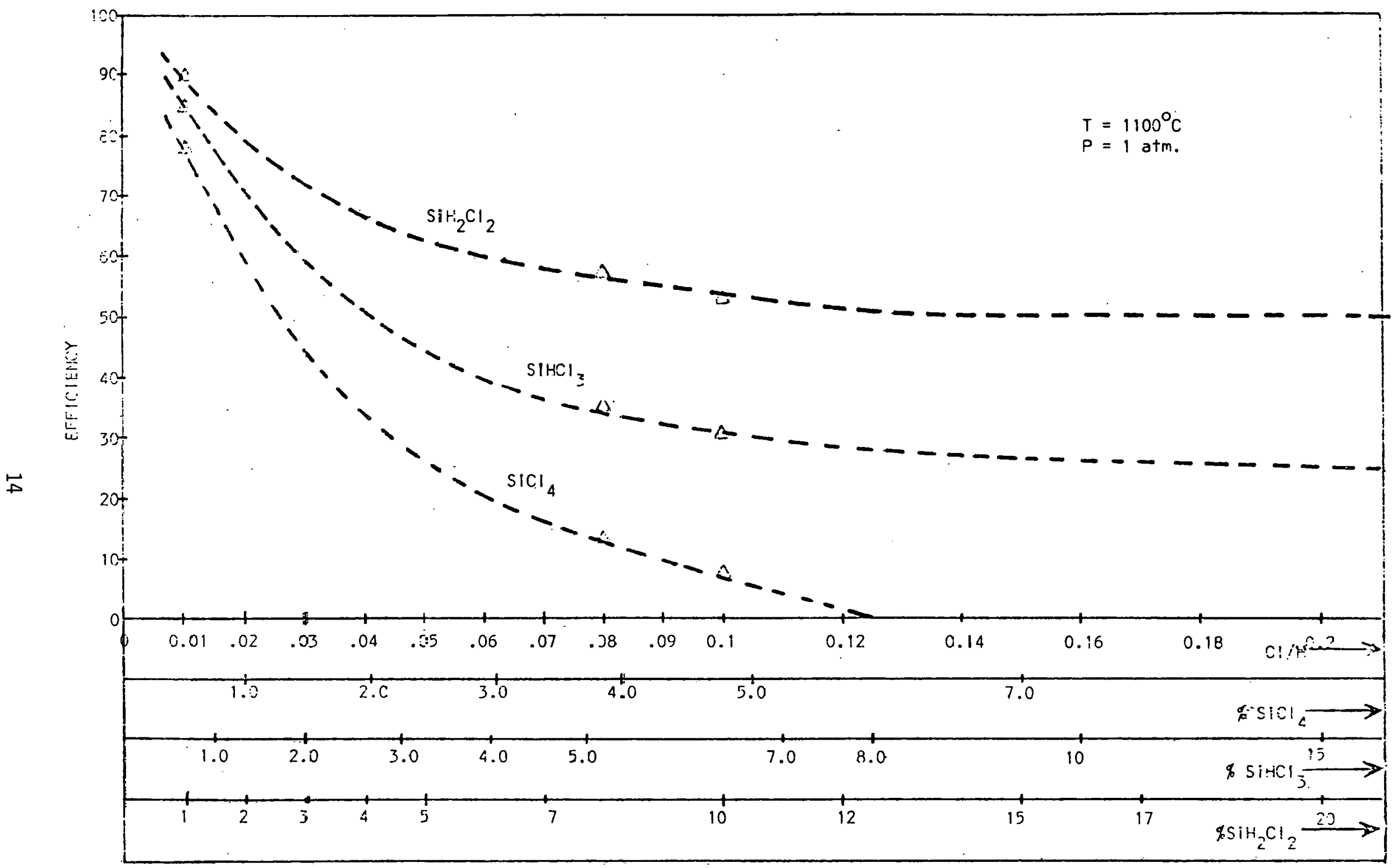

FIGURE 5: EQUILIBFIUM DEPOSITION EFFICIERICY AS A FUNCTION OF CONCENTRATION WITH DIFFERENT CILOROSILANE SOURCES FOR $T=1100^{\circ} \mathrm{C}$ and $P=1 \mathrm{~atm}$. 


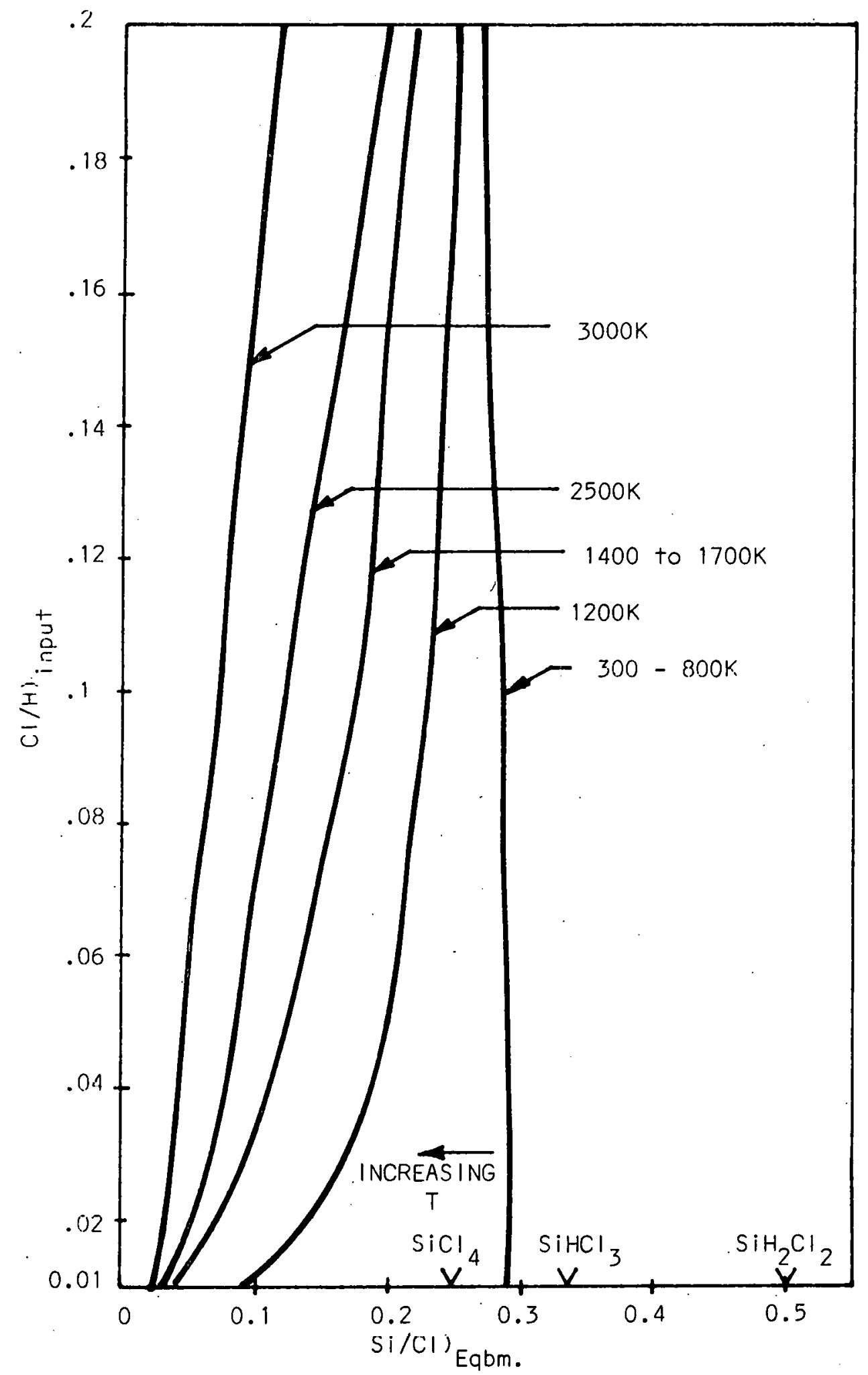

FIGIJRE $6: \quad$ Si-CI-H EQUILIBRIUM DIAGRAM GENERATED FROM THE DATA IN REFERENCES $(4-8)$. 
increasing temperature, levels off at around 1400 - $1700 \mathrm{~K}$ and then increases again. Thus, efficiency increases with increasing temperature, then levels off between 1400 - $1700 \mathrm{~K}$ and then increases further with temperature.

In a conventional CVD process, reactant gas temperature rises from room temperature to the substrate temperature, and never exceeds the substrate temperature. Thus the approach to equilibrium is from right to left in Figure 6 (low temperature to high temperature). Unless sufficient residence time is allowed, equilibrium (thermal and chemical) will not be reached. In the case of high pressure plasma deposition, the reactant gases experience very high temperatures (4) ( $4000 \mathrm{~K})$ in the plasma beam and then are quenched to the substrate temperature. Compositional equlibrium can be assumed in this high temperature, high pressure plasma. (At this time, it should be pointed out that above the boiling point of silicon, all components of the system will be in vapor phase, and the $\mathrm{Si} / \mathrm{Cl})_{\text {eqbm }}$ in Figure $\sigma$ is obtained by considering the silicon species containing $\mathrm{Cl}$ and/or $\mathrm{H}$ ). As the plasma is quenched to the substrate temperature, equilibrium is approached from the left of Figure 6 to right. By rapidly quenching the high temperature equllorium, it should be possible to obtain higher deposition efficiencies with HPP compared to CVD. Ihis has been the rationale for investigating HPP as a means for economically depositing microcrystalline sllicon films. From the experimental results, it can be seen that while the improvements in efficiencies are not as mur.h as we thrught possible, useful improvement in efficiency was indeed obtained. In the next sections we will examine the other considerations that determine the efficiency improvements obtainable with HPP silicon deposition. 
In the case of convention cold wall CVD reactors; the deposition mechanism generally involves, transport of reactants to the substrate surface, chemical reaction on the surface producing silicon atoms, and incorporation of these atoms into the growing sllicon $\mathrm{film}$, as shown in Figure 7. However, a second deposition mode involves occurrence of chemical reactions in the gas phase producing free silicon atoms, condensation of these atoms into nuclei in the gas phase, transport of these nuclel to the substrate surface and their incorporation into the growing sllicon flim. This latter mode of deposition becomes important in CVD reactors with the use of $\mathrm{SiH}_{2} \mathrm{Cl}_{2}$ and $\mathrm{SiH}_{4}$ source gases, higher substrate temperatures, and hot wall deposition systems (10-12).

With HPP deposition, however, the gas phase nucleation and deposition mode is found to be important under all conditions regardless of the type of chlorosilane, its concentration, and the reactor (substrate) temperature employed. One of the consequences of gas phase nucleation can be powder growth, l.e. sillicon nuclei, instead of reaching the substrate surface and contributing to film growth, grow in the vapor phase to a larger size and then deposit in the form of a powder. This powder formation constitutes a loss process, and furthermore creates problems in the exhaust gas (chlorosllane and hydrogen) recovery system. While it has not been, so far, possible to estimate the relative contributions of these two different deposition mechanisms in the HPP deposition process, to film deposition rates, powder formation is found to be at an inconsequential level in the horizontal operation of the system under practical film growth conditions. The reasons for this will be discussed under Section 2.4 .4 (transport effects). Figure 8 schematically illustrates the deposition model in the HPP reactor. 


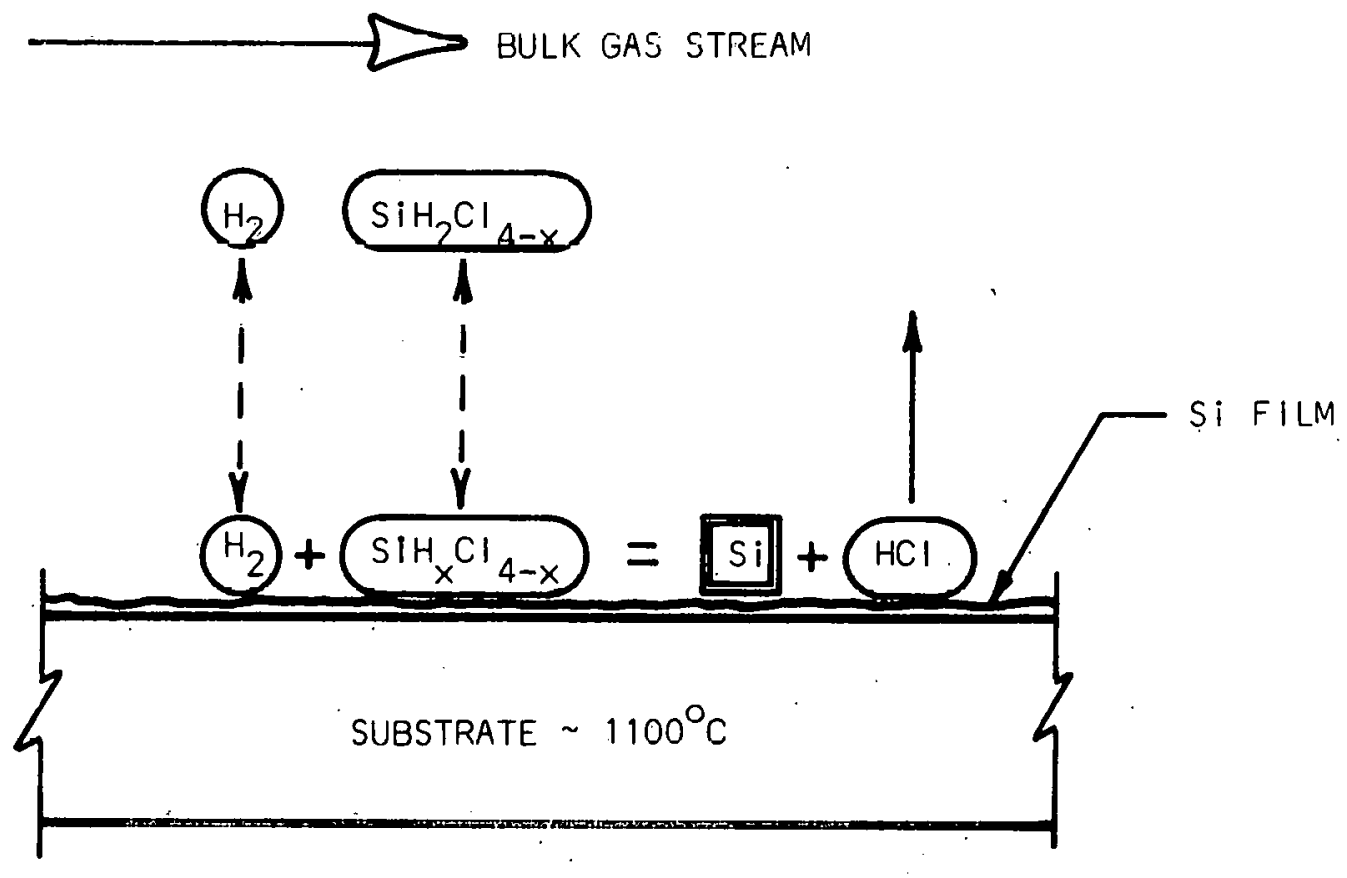

FIGURE 7: SCHEMATIC ILLUSTRATION OF THE SILICON DCFOSITION MECHANISM INJ A CONVENTIONAL COLD WALL CVD REACTOR. 


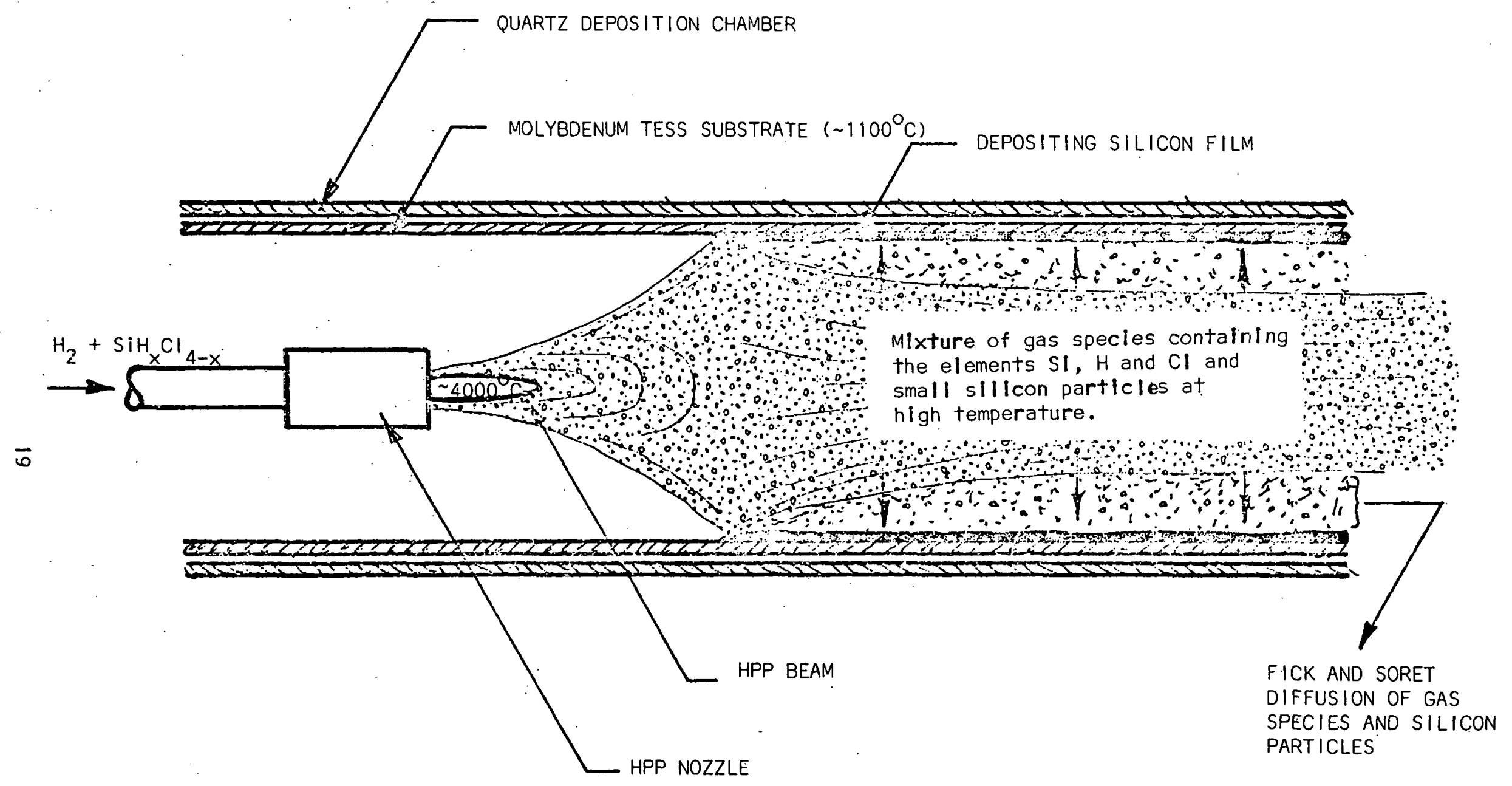

=IGURE 8: SCHEMATIC ILLUSTRATION OF THE HPP DEPOSITION MODEL. SORET DIFFUSION IS EXPECTED TO BE IMPORTANT ONLY IN THE INITIAL REGION OF THE DEPOSITION F.EACTOR. 
As discussed previously, kinetic factors determine the deposition efficiency achievable in the HPP process. Figure 9 shows equlibrium concentrations $(4,5)$ of the species present in the HPP deposition reactor. Assuming that chemical equilibrium is attained in the high temperature $(\sim 4300 \mathrm{~K})$ plasma beam, the predominant species will be $\mathrm{H}, \mathrm{Cl}$, Si $(\mathrm{g}), \mathrm{H}_{2}$ and $\mathrm{HCl}$. As the temperature is lowered through the boiling point of silicon ( 2950), there will be a driving force for condensation of silicon vapor, and upon further cooling through the melting temperature $(\sim 1683 k)$ there will be a driving force for solidification of silicon. At the same time as the temperature is lowered, there is a tendency for formation of $\mathrm{SiCl}_{2}$ and $\mathrm{SiCl}_{3}$ specles. However, silicon condensation could occur before the equilibrium $\mathrm{SiCl}_{2}$ species concentration increases. When this happens, the reaction between the condensed phase and chlorine will be the rate limiting step in the attainment equilibrium as the gas mixture is quenched. Another kinetic factor of importance is incorporation of gas phase nucleated silicon into the growing silicon film. This factor has not been found to be very important, probably because of the extremely small particle size $(\ll 1 \mu m)$, at least, in the horizontal operation of the HPP system (13). This sequence of events qualitatively explains the improvements in deposition efficlencles observed in the HPP deposition process.

2.7 .4 TRANSPORT EFFECTS

A complete discussion of the HPP deposition process has to include the various mass transport processes taking place in the deposition chamber. To develop an accurate mass transport model, chemical reactions occuring in the system 


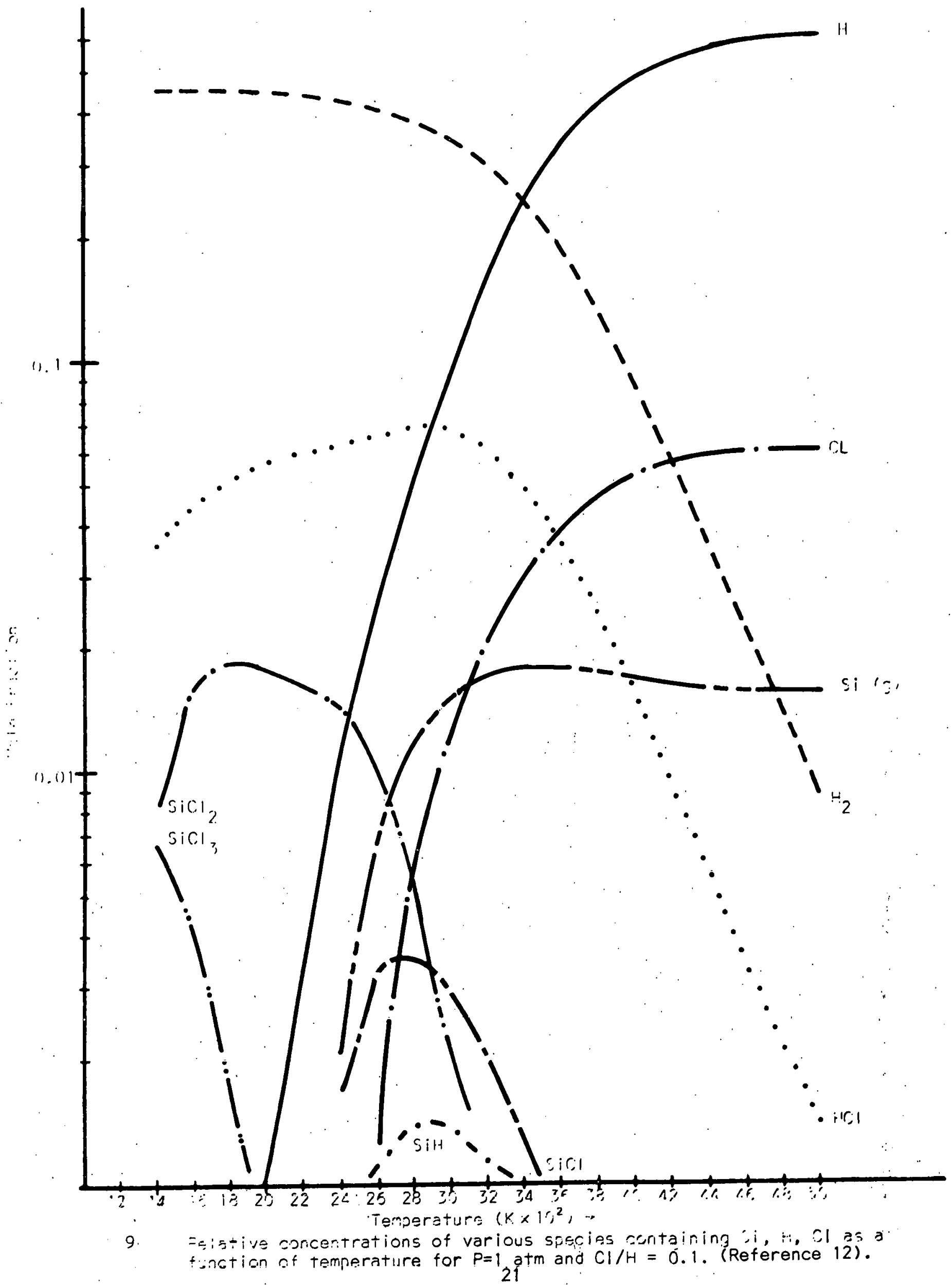


have to be consldered simultaneously. Silicon deposition reactors involving gas phase nucleation are currently being modelled by Aerochem Research Laboratories, Inc. without taking into account the simultaneous chemical reactions (see for example reference 14):

The transport of species in the HPP reactor takes place due to convective and diffusive processes driven by both compositional gradients (Fick) and thermal gradients (Soret). While the Fick diffusion coefficient for all species is positive (i.e. diffusion down the concentration gradient), the Soret diffusion coefficient will be negative for some species (i.e., in a temperature gradient lighter species tend to move towards high temperatures and heavier species towards low temperatures). Steep radial temperature gradients exist in the beginning part of the HPP reactor where the plasma core gases are hot and substrate surfaces are relatively cold. In this region, thermal diffusion is expected to be important. This situation is fortuituous since the silicon particles nucleated in the gas phase, because of their higher density compared to the reactor ambient gases, will move to the substrate surfaces due to the thermophoretic force, become incorporated, and contribute to silicon film growth. Srivastava ef al. (14) have given a good description of the particle transport properties and models in silicon deposition systems.

Apart from the transport of particles, transport of other species to and away from the substrate surface is another important factor that determines efficiency of the overall deposition system. For example in the simple reaction*

$$
\mathrm{SiCl}_{4}+\mathrm{H}_{2} \rightarrow \mathrm{SI}(\mathrm{S})+\mathrm{HCl}
$$

\footnotetext{
* The actual reaction producing free sllicon is known to involve an intermediate $\mathrm{SiCl}_{2}$ species.
} 
producing free sillicon on the substrate surface, $\mathrm{SiCl}_{4}$ has to be transported from the bulk gas stream to the substrate and $\mathrm{HCl}$ has to be transported from the substrate to the bulk gas stream. In the systems (or regions of systems) where the substrate is hotter than the bulk gas stream, diffusion of $\mathrm{SiCl}_{4} \mathrm{will}_{\text {be }}$ retarded while that of $\mathrm{HCl}$ wlll be accelerated. As a result, the substrate sees a lower chlorosilane concentration than the input value. Hence, the observed deposition efficiencies will be higher than predicted by equilibrium calculations, even with CVD.

In this discussion we have only attempted to present various factors that are important in HPP deposition. The qualitative and simplistic description of the HPP process discussed above appears to explain some of the experimental results. However further analysis is necessary to develop a quantitative HPP deposition model.

2.2 .5 CHOICE: OF SILICON SOURCE GAS

Table 3 compares various chlorosilanes. as source gases for silicon deposition by HPP. Silicon tetrachloride is the cheapest and $\mathrm{SiH}_{4}$ is the most expensive of the gases being considered. However, there is a potential for future reductions in price for $\mathrm{SiHCl}_{3}, \mathrm{SiH}_{2} \mathrm{Cl}_{2}$, and $\mathrm{SiH}$ through implementation of advanced technologies currently being developed. Due to an unfavorable market supply and dernand situation for semiconductor grade $\mathrm{siCl}_{4}$, it is currently under priced and it is expected to continue to be so, at least for the next 5 - 10 years. (Semiconductor grade $\mathrm{SiCl}_{4}$ is a biproduct of present polysilicon manufacturing plants.)

As seen in previous sections, the HPP mode of deposition improves the performance of $\mathrm{SiCl}_{4}$ and $\mathrm{SiHCl}_{3}$ as silicon source gases. However due to 


\section{TABLE 3}

COMPARISONS BETWEEN VARIOUS CHLOROSILANES

\begin{tabular}{|l|c|c|c|c|c|}
\hline \multirow{2}{*}{ CHLOROS ILANE } & \multicolumn{2}{|c|}{ TODAYS PRICE } & $\begin{array}{l}\text { POTENTIAL } \\
\text { FOR FUTURE } \\
\text { PRICE } \\
\text { REDUCTIONS }\end{array}$ & $\begin{array}{l}\text { BENEFIT } \\
\text { FROM PLASMA } \\
\text { DEPOSITION }\end{array}$ & $\begin{array}{l}\text { SIMPLICITY } \\
\text { OF DEPOSITION } \\
\text { PROCESS }\end{array}$ \\
\hline $\mathrm{SiCl}_{4}$ & 0.40 & 2.43 & $?$ & YES & YES \\
$\mathrm{SiHCl}_{3}$ & 1.60 & 7.69 & YES & YES & YES \\
$\mathrm{SiH}_{2} \mathrm{Cl}_{2}$ & 56.00 & 202.00 & YES & $?$ & $?$ \\
$\mathrm{SiH}_{4}$ & 400.00 & 475.00 & Y'ES & NO & NO \\
\hline
\end{tabular}


the low activation energy required for deposition using $\mathrm{SiH}_{2} \mathrm{Cl}_{2}$ and $\mathrm{SiH}_{4}$ sources, benefits from HPP are not expected to be significant, particularly when compared to the additional complexity of the HPP process. Furthermore, deposition using $\mathrm{SiH}_{4}$ as a source gas is expected (known) to be extremely difficult due to severe gas phase nucleation problems. Based on these considerations $\mathrm{SiCl}_{4}$ and $\mathrm{SiHCl}_{3}$ are believed to be more suitable source gases for silicon deposition. The reactor throughput rate will be about a factor of two or more when using $\mathrm{SiHCl}_{3}$ than when using $\mathrm{SiCl}_{4}$. This makes use of $\mathrm{SiHCl}_{3}$ more desirable. However, when using $\mathrm{SiCl}_{4}$, the reactor effluent gas stream contains a significant percentage of $\mathrm{SiHCl}_{3}$, and when this is recovered and recycled, use of $\mathrm{SiCl}_{4}$ as make up appears to be a more economical approach when the low price of $\mathrm{SiCl}_{4}$ is considered. 
Problems associated with operation of the present semicontinuous plasma deposition system (employing gas curtains) were discussed in the previous quarterly report. Apart from these operational problems during film deposition, another problem with this approach has been found to be associated with the use of gas curtains. Nitrogen is used in these gas curtains because of its low-cost and compatibility with the silicon deposition process. However $\mathrm{N}_{2}$ in the deposition reactor effluent will deteriously affect the performance of the recovery process. While argon is suitable (in view of its compatibility with silicon deposition and effluent recovery), it is probibitively expensive.

To overcome all the above difficulties, we have identifled a new continuous silicon film deposition scheme that does not utilize gas curtains. The new scheme, a conceptual drawing of which is shown in Figure 10, uses gas interlocks. In this system, a cassette containing a finite number of TESS substrates will be fed into the gas interlock at the entrance side of the reactor, the interlock. purged, the cassette moved into the main chamber, the substrates from the cassette translated through the deposition system, and the empty cassette withdrawn trom another interlock. By a similar scheme the substrates and separated silicon films are withdrawn from the deposition system. By proper sequencing of these operations, this process will be truly continuous. Nitrogen and hydrogen will be used in proper sequence to purge the gas interlocks so that $\mathrm{N}_{2}$ is not introduced into the deposition system when the interlock is activated. Apart from differences in the methods of intorducing and withdrawing substrates and separated films, the new prucess is identieal to the presently used one. A detailed design of this new continuous silicon film deposition system has been initiated, and it should be completed before the end of the next quarter. All four walls of the reaction chamber will be active to produce 
CONTINUAL POLYRIBBON FORMATION SYSTEM

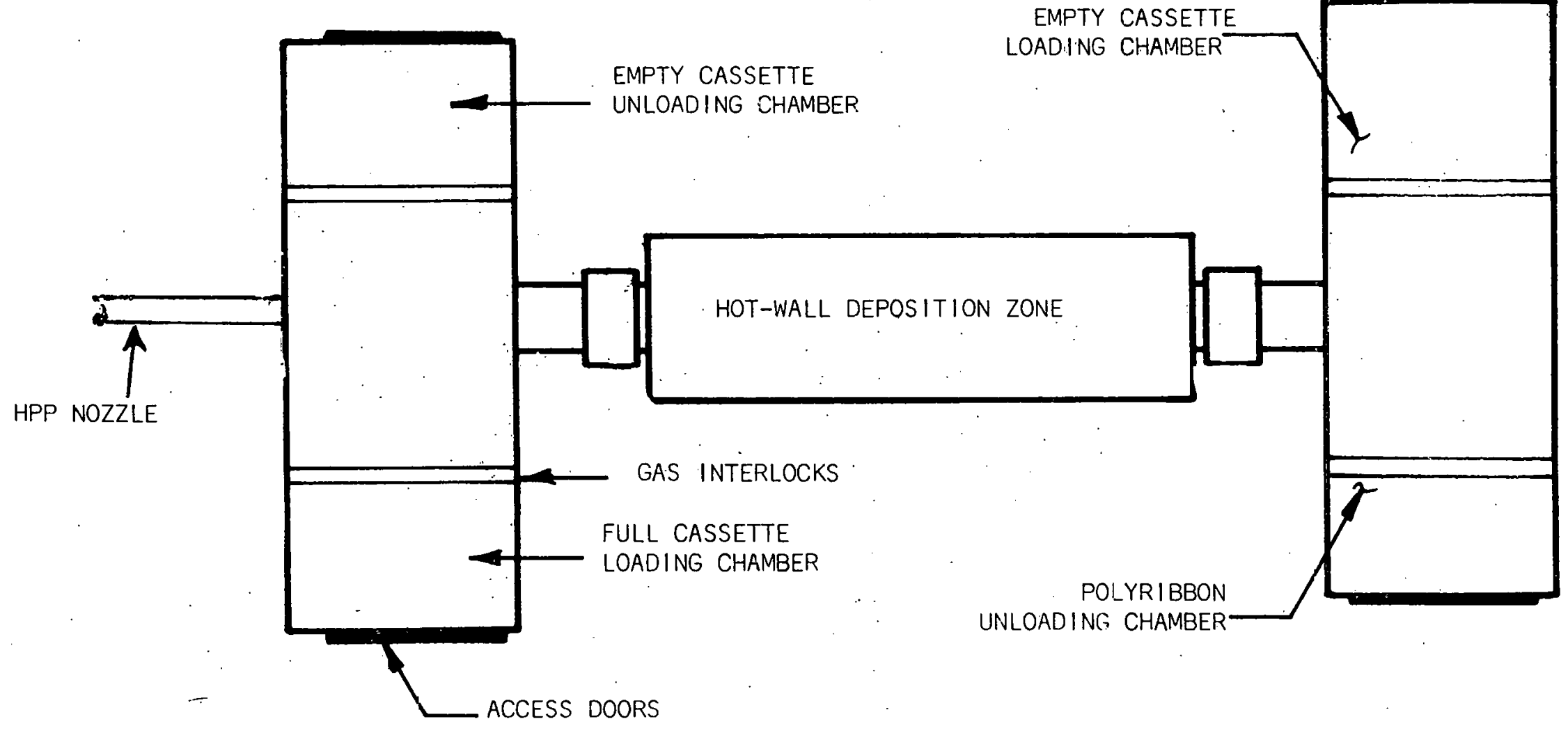

FIGURE 10: SCHEMATIC CONCEPTUAL DRAWING OF THF NEW CONTINUAI MICROCRYSTALLINE. SILICON DEPOSITION SYSTEM EMPLOYING CAS INTERLOCKS.

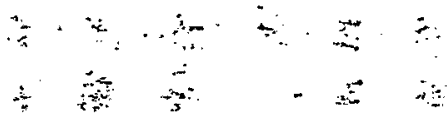


four s'ilicon films simultaneously. Silicon film (substrate) size has been selected to be about $7.5 \times \mathrm{m} \times 34 \mathrm{~cm}$ for the system design. While this system is being designed and built, we will continue to use the present semicontinuous system for producing microcrystalline silicon films. 
Although not a part of the current program, some Ribbon-to-Ribbon (RTR) laser recrystallization developments, for the sake of continuity of this report will be beiefly described. Progress has been made in two important areas: 1) development of imporved pre- and post-heaters and 2) development of a new feed mechanism. The new pre- and post-heaters were constructed from Si C elements (replacing the previous platinum helements). Performance of these new heaters is found to be much superior to the old ones" in terms of improved thermal profiles in the ribbon and lower heater down times. The new feed mechanism is more versatlle and allows grain enhancement from one end of the ribbon to the other.

Several silicon material quality related experiments were performed, by using a variety of feedstock materlals for laser recrystallization. The results of these experiments are discussed in the next section. 
In the present quarter, three separate but interrelated solar cell fabrication experiments were completed. They are described in detail in the following three subsections. The first experiment consists of "standard RTR growth" and a baseline solar cell process sequence applied to ribbons grown from high purity, oxygen-free, single crystal float zone silicon. This experiment is designed to assess the solar cell potential of RTR silicon independent of possible feedstock contamination.

The second experiment consists of solar cell fabrication on rihhnna grown trom l'vu microcrystal! ine feedstock. Two resistivities of the p-type feedstock were used, and the effect of resistivity on efficiency is discussed.

The third group of solar cells fabricated are on ribbons grown from high pressure plasma deposited microcrystalline feedstock deposited in the semicontinuous (gas curtain) apparatus.

The baseline șolar cell process sequence used. for all three groups consisted of:

$$
\begin{aligned}
& \mathrm{PH}_{3} \text { diffusion - } 18 \mathrm{~min}, 90 \mathrm{O}^{\circ} \mathrm{C} \\
& \text { Mesa Pattern Definition and Etch - Photolithography and } \mathrm{CF}(97 \%)- \\
& \qquad \mathrm{O}_{2}(8 \%) \text { plasma etching. } \\
& \mathrm{Si}_{3} \mathrm{~N}_{4} \text { AR Coating - LPCVD, } 850 \AA \text {, index of refraction }=2.0 \\
& \text { Metallization pattern definition and etch - Photolithography, } \mathrm{CF}_{4}(50 \%)- \\
& \text { Plated metal - } \mathrm{Pd}-\mathrm{Ni}-\mathrm{Cu} \text {. }
\end{aligned}
$$

This sequence uses a metallization pattern which has not been fully optimized to minimize both series resistance and the percentage of shadowing. 'As a result, the $f i l l$ factor is reduced by a factor of from 2 to $5 \%$ for the samples with short circuit current densities $\geqslant 26 \mathrm{~mA} / \mathrm{cm}^{2}$. Also, with the exception of several samples of HPP orign as noted later, no texture etching of the illuminated surface was done. 
Feedstock for RTR silicon ribbon growth was obtained by sawing a float zone silicon ingot into sheets with an area of $1.15^{\prime \prime} \times 7.5^{\prime \prime}$ and with a thickness of $10 \pm 1 \mathrm{mils}$, and etching to remove the saw damaged surfaces.

This single crystal material was recrystallized in the RTR apparatus, and the processed into solar cells using the baseline process sequence along with unmelted control samples. The recrystallized ribbons differed from grainenhanced HPP ribbons in two ways; 1) because of the quality of the starting materlal, any possible contamination from molybdenum, or from fast diffusing impurities in the molybdenum, or from the deposition furnace, are eliminated from consdieration, and 2) because the starting material was single crystal, the regrown ribbons retained the single crystallinity in some cases. The ribbons that did not retain the single crystallinity were characterized by the presence of multiple twin planes very similar to the ones in grain enhanced HPP ribbons. Table 4 summarizes the results obtained.

It can be seen from Table 4 that when single crystallinity is maintained after RTR growth, solar cell performance is scarcely different from the control cell on float zone feedstock. Thus, chemical contamination during RTR growth (from the growth chamber, pre-heater and post-heater) appears to be inconsequential. The RTR single crystal cell, however was found to contain higher dislocation density $\left(7 \times 10^{4} / \mathrm{cm}^{2}\right)$ compared to the float zone single crystal control cell.

\subsection{SOLAR CELLS ON RTR SILICON GROWN FROM CVD FEEDSTOCK}

Ribbons grown from CVD microcrystalline feedstock were divided into two groups; a low resistivity $(\sim 0.30 \Omega-\mathrm{cm}$ lot) and a moderate resistivity lot $(\sim 2.4 \Omega-\mathrm{cm})$. The results on solar cells fabricated by the baseline process 
TABBLE 4

SUMMARY OF RESULTS OBTAINED USING FLOAT ZONE SILICON FEEDSTOCK.

\begin{tabular}{|c|c|c|c|}
\hline SOLAR CELL DESCRIPTION & AMI EFFICIENCY (q) & $J_{S C}\left(\mathrm{~mA} / \mathrm{cm}^{2}\right)$ & $v_{O C}($ volts $)$ \\
\hline $\begin{array}{l}\text { Float Zone single Crystal } \\
\text { Control }\end{array}$ & 14.8 & 32.3 & .606 \\
\hline $\begin{array}{l}\text { RTR single Crystal } \\
\text { (F!nat Znne Feadstork) }\end{array}$ & 14.5 & 31.4 & .601 \\
\hline $\begin{array}{l}\text { RTR Heavily Twinned } \\
\text { (Float Zone Feedstock) }\end{array}$ & 13.0 & 30.7 & .586 \\
\hline $\begin{array}{l}\text { Best RTR Cell-Oxygen Free, } \\
\text { CVD Feedstock }\end{array}$ & 12.8 & 27.5 & .608 \\
\hline
\end{tabular}


sequence are presented in table 5. The loss in $\mathrm{J}_{\mathrm{SC}}$ due to doping effects on diffusion length, as resistivity is lowered, is more than made up for by the incroase in $V_{O C}$. The difference in flll factor between the two lots is small, and is partially an artifact of the non-optimum grid design used. The metallization pattern used provides the optimal tradeoff between shadowing of the junction and resistive losses for cells having short circuit currents of up to $26 \mathrm{~mA} / \mathrm{cm}^{2}$. Since these cells average better than this, the flll factor is reduced from what a better pattern could provide, and the effect (i.e. amount of reduction) will be slightly greater for the $2.4 \Omega-\mathrm{cm}$ lot. An estimate of the quantitative effect of this grid design on fili factor was obtained for one cell (1185A-4B, with $V_{O C}=.608, J_{S C}=27.5 \mathrm{~mA} / \mathrm{cm}^{2}$, and $F . F .=77.0 \%$ ) by numerically fitting the $i-v$ characteristics and subtracting the effect of a constant, lumped serles resistance. This allowed for the calculation of a "semiempirical" fill factor, which in this case worked out to be $80.1 \%$. This represents an upper limit dictated entirely by the short circult current and the junction $i-v$ properties. An optimal grid design can be expected to increase the actual fill factor $1-2$ percentage points.

Another cell (with $n=11.9 \%$ ) from the low resistivity lot was given a $6 \mathrm{~min}$. Wright etch to delineate dislocations. The results for a front surface etch are shown in Figure 11 and for a cross section in Flgure 12 . These results are typical of present day RiR sllicon (grown from microcrystalline feedstock), and appear to be improvable by further work on the post-heater thermal profile. It is somewhat surprising (and encouraging) that solar cells with efficiencies of $12-13 \%$ can be made on material having regions with high $\left(\geqslant 1 \times 10^{6} / \mathrm{cm}^{2}\right)$ dislocation density. 
TABLE 5

RTR SOLAR CELL PERFORMANCE FROM CVD FEEDSTOCK

\begin{tabular}{|c|c|c|c|c|c|c|c|c|}
\hline \multirow{2}{*}{$\begin{array}{l}\text { RESISTIVITY } \\
\Omega-\mathrm{ciII}\end{array}$} & \multicolumn{2}{|c|}{ AMI EFFICIENCY (q) } & \multicolumn{2}{|c|}{$J_{\mathrm{sc}}\left(\mathrm{mA} / \mathrm{cm}^{2}\right)$} & \multicolumn{2}{|c|}{$v_{0}\left(v_{0} \mid t s\right)$} & \multicolumn{2}{|c|}{$F . F:(\phi)$} \\
\hline & AVE. & $\operatorname{MAX} X^{*}$ & Sर्रि. & MMX* & AfE. & MAX** & AVE. & MAX: \\
\hline 2.4 & 11.04 & 12.2 & 29.0 & $30.9^{\circ}$ & 0.52 .1 & 0.537 & 73.0 & 75.8 \\
\hline 0.3 & 11.65 & 12.8 & 26.43 & 29.3 & 0.595 & 0.608 & 74.2 & 78.8 \\
\hline
\end{tabular}

*Maximum values not obtained simultaneously. 


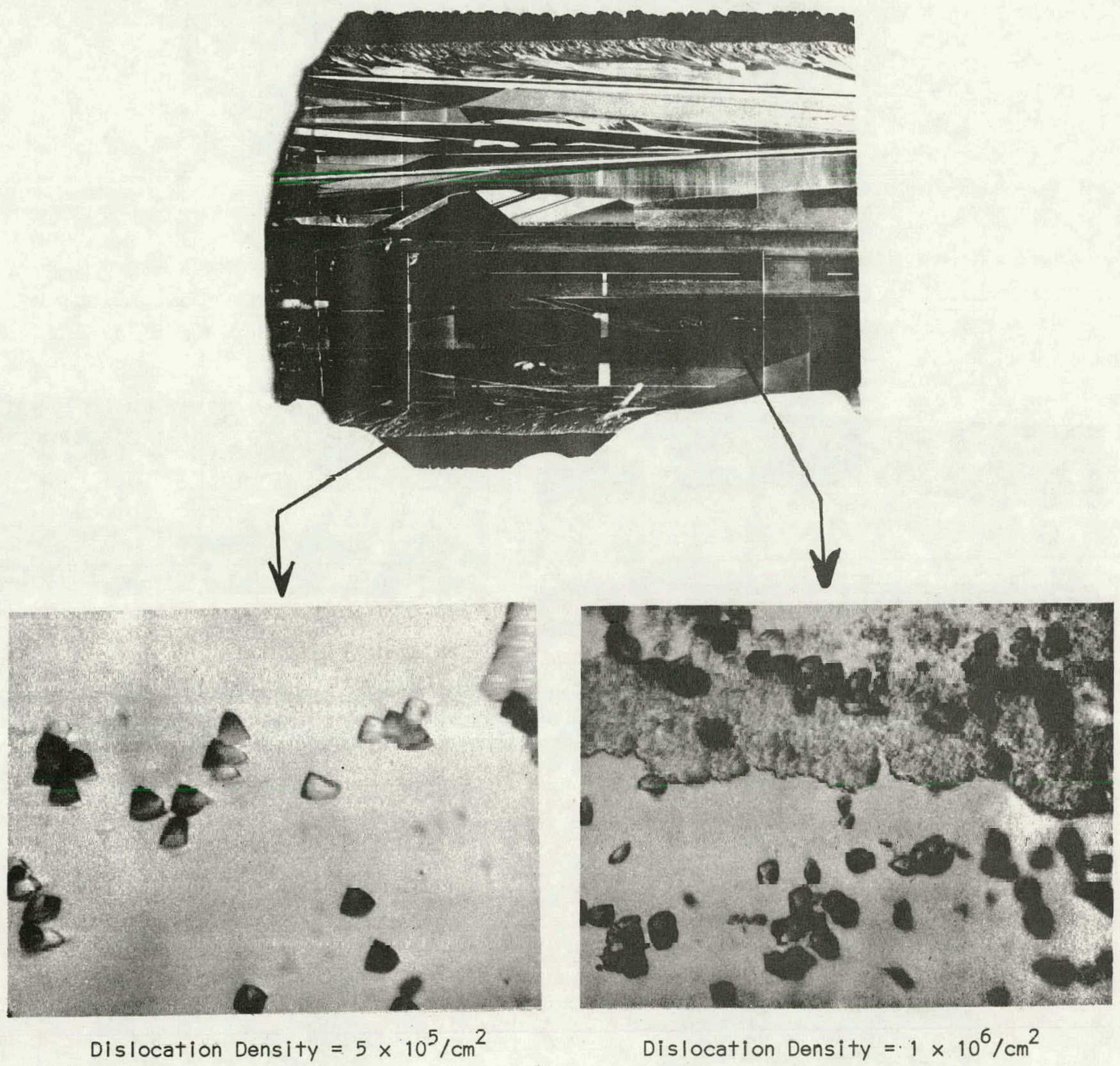

FIGURE 11: DISLOCATION ETCH PITS ON THE SURFACE OF A CELL AS REVEALED BY 6 MINUTES WRICHT ETCIIING. 


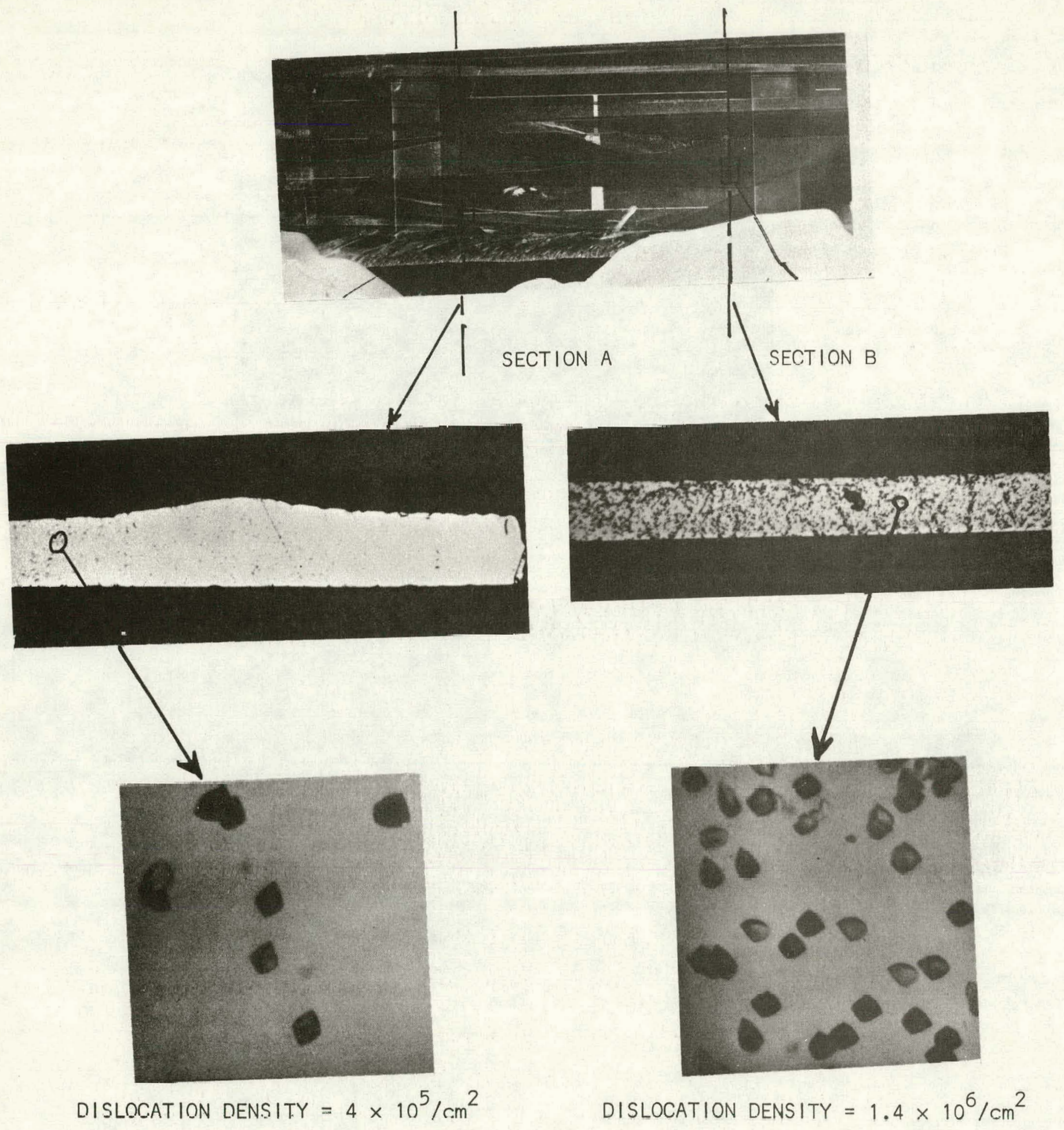

FIGURE 12: DISLOCATION DENSITY IN THE BULK OF THE CELL SHOWN IN FIGURE 11, AS REVEALED BY WRIGHT ETCHING THE CROSS SECTIONAL SAMPLES. 
Results on typical solar cells fabricated on grain enhanced HPP films are summarized in Table 6. Unlike the cells fabricated on RTR rpocessed float zone or CVD feedstock reported in the previous sections, some of the HPP cells were larger in size $(2 \mathrm{~cm} \times 2 \mathrm{~cm})$. Also some of these cells were fabricated on textured surfaces (to minimize front surface reflection) as indicated in Table 6. Another difference between the float zone feedstock and HPP feedstock is the silicon thickness; thickness of HPP feedstock was around $175 \mu \mathrm{m}$, whereas that of float zone was around $250 \mu \mathrm{m}$.

The highest efficiency observed in this lot was about $12 \%$, and was on $2 \mathrm{~cm} \times 2 \mathrm{~cm}$ area textured cell shown in Figure 13. The other parameters of this cell are: $V_{O C}=0.582$ volts, $J_{S C}=28.3 \mathrm{~mA} / \mathrm{cm}^{2}$ and $F . F .=73.0 \%$. The defect structure of these grain enhanced HPP films is similar to the ones reported in the previous quarterly report (12), since the same recrystallization parameters were employed.

Comparing the results obtained with the float zone, CVD and, HPP silicon ribbons, it appears that the major factor limiting the performance of the HPP or CVD films is the defect density of the grain enhanced films, and not the chemical purity of the feedstock material. Thus, when the defect density (dislocations, incoherent twin boundaries and grain boundaries) is reduced by optimization of RTR grain enhancement growth parameters, further improvements in solar cell conversion efficiency can be expected. 
TABLE 6

SUMMARY OF TYPICAL SOLAR CELLS FROM GRAIN

ENHANCED HPP DEPOSITED FILMS

\begin{tabular}{|c|c|c|c|c|c|c|c|}
\hline \multicolumn{2}{|c|}{ CELL I.D. } & \multirow{2}{*}{$\begin{array}{l}\text { CELL SIZE } \\
(\mathrm{cm} \times \mathrm{cm})\end{array}$} & \multirow{2}{*}{$\begin{array}{c}\mathrm{V}_{\mathrm{OC}} \\
\text { (volts) }\end{array}$} & \multirow{2}{*}{$\begin{array}{c}\mathrm{J}_{\mathrm{Sr}} \\
\left(\mathrm{mA} / \mathrm{cm}^{2}\right)\end{array}$} & \multirow{2}{*}{$\begin{array}{l}F . F . \\
(\%)\end{array}$} & \multirow{2}{*}{$\begin{array}{c}n(A M 1) \\
\left(\begin{array}{l}(a) \\
n\end{array}\right)\end{array}$} & \multirow{2}{*}{ COMMENTS } \\
\hline HPP & RTR & & & & & & \\
\hline \multirow[t]{3}{*}{$13-9$} & $1201 \mathrm{C}-1$ & $1 \times 2$ & 0.541 & 23.0 & 71.5 & 8.9 & Non-textured \\
\hline & -2 & $1 \times 2$ & 0.559 & 25.0 & 70.8 & $9 . \dot{9}$ & $"$ \\
\hline & -3 & $1 \times 2$ & 0.561 & 25.0 & 72.7 & 10.2 & $"$ \\
\hline \multirow[t]{3}{*}{$17-4$} & $1201 G-1$ & $2 \times 2$ & 0.579 & 25.6 & 75.6 & 11.2 & Textured \\
\hline & -2 & $2 \times 2$ & 0.582 & 20.0 & 74.5 & 11.3 & " \\
\hline & -3 & $2 \times 2$ & 0.580 & 26.3 & 70.4 & 10.7 & $"$ \\
\hline \multirow[t]{2}{*}{$18-4$} & $1201 \mathrm{~B}-1$ & $1 \times 2$ & 0.577 & 25.8 & 74.6 & 11.1 & Non-textured \\
\hline & -2 & $1 \times 2$ & 0.575 & 24.5 & 71.0 & 10.0 & $"$ \\
\hline $18-6$ & $1201 E-1$ & $2 \times 2$ & 0.582 & 28.3 & 73.0 & 12.0 & Textured \\
\hline \multirow[t]{3}{*}{$21-6$} & $1219 A-1$ & $2 \times 2$ & 0.573 & 26.7 & 73.9 & 11.3 & $"$ \\
\hline & -2 & $2 \times 2$ & 0.570 & 26.5 & 69.5 & 10.5 & $"$ \\
\hline & -3 & $1 \times 2$ & 0.558 & 25.5 & 69.6 & 9.9 & $"$ \\
\hline
\end{tabular}




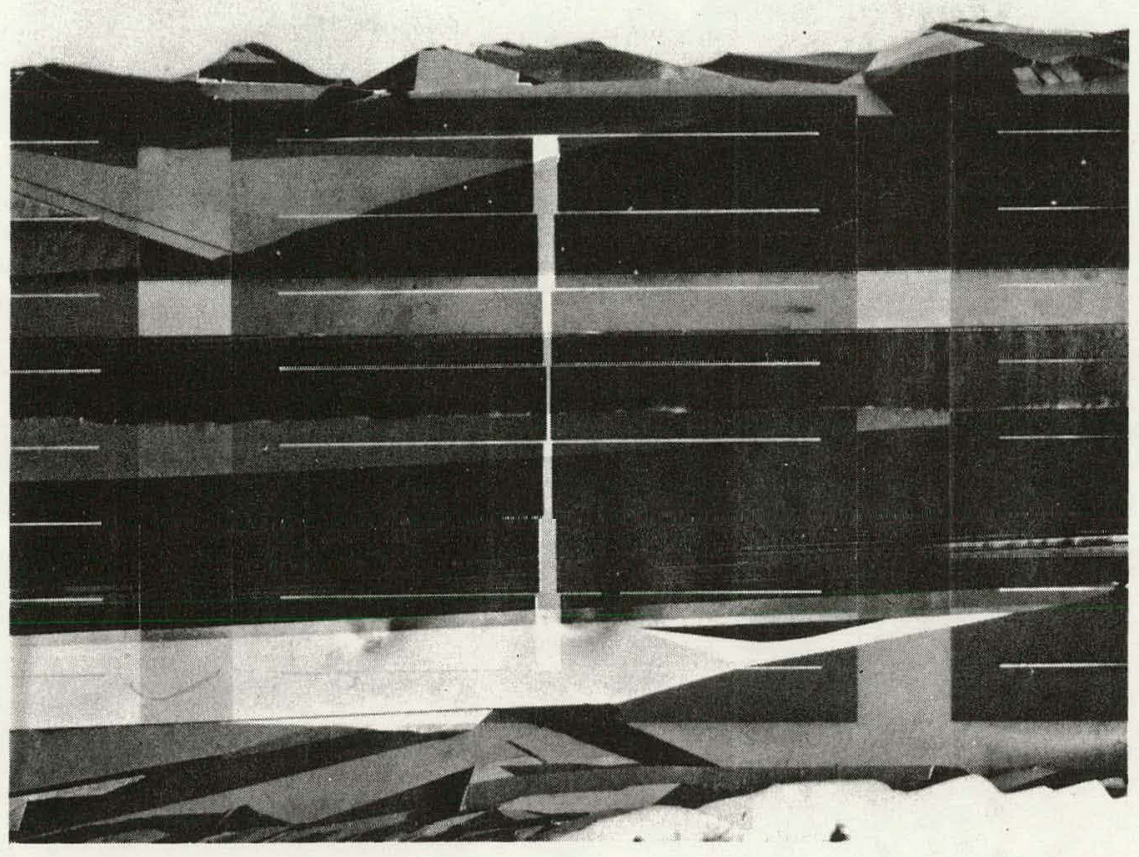

FIGURE 13: PHOTOGRAPH OF A 12\% AM1 EFFICIENCY

$(2 \mathrm{~cm} \times 2 \mathrm{~cm}$ AREA) CELL FABRICATED ON A GRAIN ENHANCED HPP DEPOSITED SILICON FILM. $V_{O C}=0.582 \mathrm{~V}, J_{S C}=28.3 \mathrm{~mA} / \mathrm{cm}^{2}$ and $\mathrm{FF}=93.0 \%$. 
During the next quarter we plan to:

- Continue periodic TESS substrate resurfacing experiments.

- Complete design of the continuous silicon film deposition system employing gas interlocks.

- Continue operation of the existing semicontinuous plasma deposition system, and

- Demonstrate $>12 \%$ AM1 conversion efficiency on $>10 \mathrm{~cm}^{2}$ area solar cells fabricated on grain enhanced plasma deposited silicon films. 
1. K. R. Sarma, et al., Thin Film Polycrystalline Silicon Solar Cells, Quarterly Report 1, Dec. 1979, DOE Contract No: XS-9-8277-1.

2. K. R. Sarma et al., Thin Fllm Polycrystalline Silicon Solar Cells, Quarterly Report 2, March 1980, DOE Contract No. XS-9-8277-1.

3. C. W. Monke and L. F. Donaghey, J. Electrochem. Soc., 124, 561 (1977).

4. K. R. Sarma et al., Thin Films of Silicon on Low-Cost Substrates, Final Report, Sept. 1978, DOE Contract No. EY-76-C-03-1287.

5. K. R. Sarma et al., in Proc. 13th IEEE Photovoltaic Speclalists Conference, PP 466, June 1978, Washington D.C.

6. L. P. Hunt et al., Proc. 2nd International Conference on Chemical Vapor Deposition, PP. $3-24,1969$.

7. E. Sirtl et al., J. Electrochem. Soc., 121, 925 (1974).

8. L. P. Hunt et al., J. Ėlectrochem. Soc., 119, 1741 (1972).

9. JANAF Thermo Chemical Tables, Ed. D. R. Stull, Constantly updated.

10. F. C. Eversteijn, Philips Research Reports, 26, 134 (1971).

11. T.U.M.S. Murthy et al., J. Crystal Growth, 33, 1 (1976).

12. K. J. Sladek, J. Electrochem. Soc., 118, 654 (1971).

13. K. R., Sarma et al., Thin Film Polycrystalline Silicon Solar Cells, Annual Report, Sept. 1979, DOE Contract No. ET-78-C-03-2207.

14. R. Srivastava and R. K. Gould, Development of a Model and Computer Code to Describe Solar Grade Silicon Production Processes, 7th Quarterly Report, August 1979, DOE/JPL 954862-79/7. 